\title{
Joint Stock Company
}

National Cancer Institute

\section{Source}

National Cancer Institute. Joint Stock Company. NCI Thesaurus. Code C54134.

A company which has some features of a corporation and some features of a partnership. The company sells fully transferable stock, but all shareholders have unlimited liability. 